\title{
Forum
}

\section{Taking the broad view of conservation - A response to Adams and Hulme}

\author{
David Western
}

Adams and Hulme (this issue) address the critics who see community conservation (CC) as a challenge to state-led, scientific management of biodiversity. The uncritical adoption of $\mathrm{CC}$ initiatives certainly merits skepticism, but casting community and state programs as somehow mutually exclusive (Oates, 1995), or as conservation versus disguised development (Terborgh, 1999), is equally simplistic, as the authors point out. Does a community have to prove that it does better at conservation than a park? Of course not, any more than a park has to prove it does better than a community initiative, habitat restoration, species reintroduction or any other conservation technique. Adams and Hulme argue that $\mathrm{CC}$ is here to stay and that it should be seen as the mixture of development-cum-conservation and one of many conservation tools. By exploring where community efforts fit and where they do not, they defuse the empty debate about the single best conservation method. They go on to ask who should set conservation objectives, and how trade-offs can be negotiated.

A note first on terminology: I prefer the term community-based conservation (CBC) to $\mathrm{CC}$, if only because it has been widely adopted (Western \& Wright, 1994). Whatever the label, the locus of action is local, rural and collaborative, rather than government-driven and focused on protected lands.

The authors are right to put $C B C$ under the microscope, but I would add that all conservation methods should be judged equally. Were the same standard of proof to be applied to parks, for example, the jury would be mixed. Kenya is a typical example, with wildlife numbers in decline in most districts (Githaiga, 1998). Although some parks are holding their own, others, including Maasai Mara, show falling numbers, (Ottichilo, 2000). The same is true of CBC areas. Some continue to lose wildlife but there is quantitative evidence to show that on balance wildlife numbers are stable or increasing compared with background trends (Githaiga, 1998). Without a common standard of proof, arguments about success and failure are futile and do not help conservation managers focus their efforts.

David Western Wildlife Conservation Society and African Conservation Centre, Box 62844, Nairobi, Kenya. E-mail: DWes107394@aol.com

Manuscript accepted 14 March 2001
Adams and Hulme are also correct that $\mathrm{CBC}$ is not one thing but many, although again, the same can be said of all conservation methods. Most community efforts are directed at conserving water, soils, fuelwood and other natural resources rather than biodiversity. Likewise, until a few decades ago, most protected areas were set aside for aesthetic, recreational or other reasons, rather than for biodiversity (Hales, 1989). Only now are IUCN, WWF and Conservation International addressing the lack of biodiversity conservation coverage through campaigns for the conservation of habitats and species hotspots. The same can be said of fish and wildlife agencies, which still manage 'game' outside protected areas, largely for sport rather than for biodiversity.

Apply the harsh rule of proof, and few methods will conserve more than a fraction of the world's biodiversity. Only in combination, and by conserving an order of magnitude more land, linked across entire continents, can our conservation arsenal save the majority of earth's species.

$\mathrm{CBC}$ is no exception to the limitations of each method. All too often we isolate and pit one strategy against another in a conservation popularity contest, each with its own aphorisms. Parks become the fence-and-fine approach, or protectionism. CBC becomes the human face of conservation, or conservation-and-development. The distinctions are useful, but turn trivial when cast in opposition rather than as complementary strategies. Sometimes the distinctions are myopic: CBC is often disparaged as a use-it-or-lose-it philosophy, overlooking the fact that parks and enforcement are judged economically, albeit disguised in income taxes and weighed against other government services.

Adams and Hulme move us beyond territorial barbs to the firm ground of assessment. I whole-heartedly agree that like it or not, CBC is here to stay. However, their assertion needs reinforcement, for the sake of those who prefer to ignore the global political and economic trends, especially in Africa.

From the late 19 th to mid-20th century, nation states and colonialism were the driving force behind the rise of modern conservation, largely as a result of resource shortage and wildlife plunder. Setasides and enforcement slowed the losses, and still do, but times are now different, and so are the conservation challenges. 
Today, we cannot pretend that humans and nature live apart, or that we can isolate pristine fragments of nature. We now live in a human-dominated world where no species or ecosystem is beyond our influence (Science, 1997).

Population growth and resource extraction are not the only problems - economic and political change is equally threatening (Western, 2000). Democracy is raising issues of rights across Africa. Societies are no longer cowed, but actively challenge their governments, asserting that they have no right to usurp land for parks or to expect landowners to suffer crop and livestock depredations without redress. In part $C B C$ is recognition of these grassroots challenges to conservation, and of the need to win the broad civil support that conservation enjoys in Europe and the USA.

Yet another factor making conservation across the landscape unavoidable is our changing science paradigm. Parks, isolated from each other, will become as impoverished as oceanic islands (MacArthur \& Wilson, 1967) and, more recently, we have come to understand that diversity within any ecosystem depends on the continuous recharge of species from a regional and continental scale over millennial time spans (Rosenzweig, 1995). Furthermore, we no longer see ecosystems as self-regulating machines, simple and closed, but as complex, open systems (Botkin, 1990), connected through global processes that are heavily influenced by human activity (Science, 1997).

So, where setasides, preservation, ecological containment and enforcement made headway for decades, today they are necessary but wholly insufficient measures. Put simply, we are running out of uncontested land for preservation: new setasides worldwide declined from 260 to 40 a year between the 1980s and 1990s. African states can no longer move people like chess pieces or cudgel and cajole them when bureaucracies are shrinking, civil society is growing and landowners are ever more conscious of their rights.

These are not the views of weak-kneed conservationists, but of experienced protectionists too. To quote the views of the World Commission on Protected Areas (WCPA): 'Where once parks were planned against people, WCPA now advocates they be planned with local people. Fifty years of experience has taught us that protected areas cannot survive and flourish in isolation.

Adams and Hulme sensibly draw us back from the dead-end debate of protectionist and utilitarian extremism. They direct us to where $\mathrm{CBC}$ fits into a humandominated world, by tabulating conditions under which it works. Weber (1998) constructed similar matrices for a negotiations-by-the-rules approach to environmental conflict that leads to lower transaction costs and improved conservation.
Recognizing that $\mathrm{CBC}$ works best for sustaining natural resources rather than biodiversity is a step forward. Biodiversity benefits are too diffuse, and the losses so slow to manifest themselves, that they barely tip our here-and-now economic scales. Consequently, landowners pluck the few benefits that do yield quick rewards, such as ecotourism. In short, we cannot save biodiversity by free-market forces alone, or by pure selfinterest. We need to think at a big scale and over the long-term.

To do so, however, we must go beyond Adams and Hulme's best-fit matrix, to design biodiversity networks that cover the diversity of habitats and species and the landscape connections between them. Kenya, for example, is working towards a Minimum Viable Conservation Network, linked to neighbouring countries (Western, 2000). The MVCA incorporates critical protected and non-protected areas and the landscape linkages for sustaining biodiversity. The best-fit conservation approach is encouraged within the MVCA, whether as wildlife sanctuaries, ecotourism, utilization or leases. Agency and donor funds draw landowner and NGO attention to the critical locations and use regular audits to monitor performance.

This is how policy can make a difference in creating the enabling conditions for $\mathrm{CBC}$ and other conservation methods. Kenya, for example, encourages $\mathrm{CBC}$ by building the capacity of wildlife associations, and progressively devolving more rights and responsibilities to them (Western, 2000). The role of the Kenya Wildlife Service can, consequently, focus more on protected areas, policy formulation and oversight. This policy encourages methods and partnerships that work best in a pluralistic setting. Over $2000 \mathrm{sq} \mathrm{km}$ of community wildlife sanctuary have been established for ecotourism, and other communities benefit from wildlife culling.

Policy can also redress another problem at the root of biodiversity loss - inequality. A fallacy of protectionism is that we can ignore the costs locally. A fallacy of $\mathrm{CBC}$ is that we can conserve biodiversity through free-market economics. But why, if we subsidize health care, education and agriculture in the interests of national progress and security, shouldn't we do the same for biodiversity?

Perverse subsidies prop up adverse use of the environment and deflate the long-term benefits of biodiversity (Myers \& Kent, 1998). Removing perverse subsidies and supporting long-term environmental health can be achieved by full-cost accounting, sound development principles and supporting policy (Dailey, 1997). Conservation easements, leases and trust funds are some of the new mechanisms for redressing the social inequality and long-term imbalances through community participation. 
A national and global conservation network, supported by enabling policy is, in other words, a way of placing Adams and Hulme's best-fit matrix in a multistrategy, multi-local context. It also addresses their two final questions: Who defines conservation objectives and how are the negotiations between actors decided?

The answer to the first question is, increasingly, civil society. Civil society will decide biodiversity's future, either as isolated pockets, or connected throughout the landscape. Equally, government has a new and larger role in defining the goals, framework and policy for conservation, overseeing its implementation, and linking national efforts through global strategies (Western, 2000).

The answer to the second question is that policies, procedures, institutions, and modes of negotiation and arbitration will increasingly be undertaken by a broad coalition of international institutions, governments and civil society.

Adams and Hulme sensibly steer us away from narrow rhetoric to pluralism in conservation. We cannot treat any conservation method in isolation, and conservation must be integral to human goals and practices at every level. Inevitably, that calls for economic, political and institutional linkages across landscapes and through time that match the scale at which biodiversity itself is determined. Adams and Hulme have made an important contribution to the bigger picture.

\section{References}

Botkin, D.B. (1990) Discordant Harmonies: A New Ecology for the Twenty-First Century. Oxford University Press, New York.

Dailey, G.C. (ed.) (1997) Nature's Services: Societal Dependence on Natural Ecosystems. Island Press, Washington DC.

Githaiga, J. (1998) Recent Wildlife Trends in Kenya. Kenya Wildlife Service, Nairobi, Kenya.
Hales, D. (1989) Changing concepts of national parks. In Conservation for the Twenty-First Century (eds D. Western and M. Pearl), pp. 139-144. Oxford University Press, New York.

MacArthur, E. \& Wilson, E.O. (1967) The Theory of Island Biogeography. Princeton University Press, Princeton, NJ.

Myers, N. \& Kent, J. (1998) Perverse Subsidies. Institute for Sustainable Development, Canada.

Oates, J.F. (1995) The dangers of conservation by rural development: a case study from the forest of Nigeria. Oryx, 29, 115-122.

Ottichilo, K.W. (2000) Wildlife Dynamics. An Analysis of Change in the Masai Mara Ecosystem of Kenya. ITC Publication Series no. 70. Wageningen, the Netherlands.

Rosenzweig, M.L. (1995) Species Diversity in Space and Time. Cambridge Univeristy Press, Cambridge.

Science (1997) Human-dominated ecosystems. Science, 277, 485-525.

Terborgh, J. (1999) Requiem for Nature. Island Press, Washington DC.

Weber, E.P. (1998) Pluralism by the Rules. Conflict and Cooperation in Environmental Regulation. Georgetown University Press, Washington DC.

Western, D. (2000) Conservation in a human-dominated world. Issues in Science and Technology, Spring, 1-14.

Western, D. \& Wright, M. (eds) (1994) Natural Connections. Perspectives in Community-Based Conservation. Island Press, Washington DC.

\section{Biographical sketch}

David Western is a senior conservationist with the Wildlife Conservation Society and chairman of the African Conservation Centre, Nairobi. He began work on communitybased conservation among the Amboseli Maasai in 1967 and continues to promote $C B C$, most recently as director of the Kenya Wildlife Service (1994-98). 